\title{
Pengaruh Terapi Gizi Klinik Intensif Terhadap Penurunan Berat Badan, Komposisi Tubuh, dan Profil Lipid pada Remaja Overweight dan Obesitas
}

\author{
Rita Halim, Raihanah Suzan, Maria Estela Karolina \\ Fakultas Kedokteran dan IImu Kesehatan Universitas Jambi \\ ritahalim84@gmail.com
}

\begin{abstract}
Background: Current nutritional status issues are no longer focused on malnutrition, but also on excess nutrition that can occur in all age groups, especially vulnerable to occur at a young age. Objective: to assess the effect of intensive clinical nutrition therapy on weight loss, body composition and lipid profile in overweight and obese adolescents. Method: This study was a case control study and was carried out during the months of August - September 2018, where the sample of the study would be antopometric examination, body composition and lipid profile before and after the intervention. Results: there was no significant difference in the effect of intervention between intensive nutrition therapy compared to only nutrition counseling in weight loss, body composition, and lipid profile. Conclusion: Nutritional intervention in the form of intensive nutrition therapy and counseling conducted in this study had significant results in weight loss, lipid profile and body composition in overweight and obese adolescents, although no significant effect was found on the two interventions.
\end{abstract}

Keywords: Nutritional intervention, weight loss, body compotition, lipid profile, overweight, obesitas

\section{ABSTRAK}

Latar belakang: Permasalahan status gizi saat ini bukan lagi hanya terpusat pada kekurangan gizi saja, namun juga pada kelebihan gizi yang dapat terjadi pada semua golongan usia, terutama rentan terjadi pada usia muda. Tujuan: menilai pengaruh terapi gizi klinik intensif terhadap penurunan berat badan, komposisi tubuh dan profil lipid pada remaja overweight dan obesitas. Metode: Penelitian ini merupakan penelitian case control dan dilakukan selama bulan Agustus - September 2018, dimana sampel penelitian akan dilakukan pemeriksaan antopometri, komposisi tubuh dan profil lipid sebelum dan sesudah intervensi. Hasil: tidak terdapat perbedaan pengaruh intervensi secara bermakna antara terapi gizi intensif dibandingkan dengan hanya penyuluhan gizi saja dalam menurunkan berat badan, komposisi tubuh, dan profil lipid. Kesimpulan : intervensi gizi berupa terapi gizi intensif dan penyuluhan yang dilakukan pada penelitian ini memiliki hasil yang bermakna terhadap penurunan berat badan, profil lipid dan komposisi tubuh pada remaja overweight dan obesitas walaupun tidak ditemukan perbedaan yang bermakna dari kedua intervensi tersebut.

Kata Kunci: intervensi gizi, penurunan berat badan, komposisi tubuh, profil lipid, overweight, obesitas 


\section{PENDAHULUAN}

Permasalahan status gizi saat ini bukan l i hanya terpusat pada kekurangan gizi Saja, namun juga pada kelebihan gizi yang dapat terjadi pada semua golongan usia, terutama rentan terjadi pada usia muda.Menurut World Health Organization (WHO) menyatakan komposisi tubuh manusia yang ideal untuk mencapai status gizi yang ideal pula terdiri dari komposisi anatomik seperti oksigen, karbon, hidrogen, nitrogen, kalsium dan fosfor. Komposisi molekular seperti lemak, protein, glikogen, air, dan mineral. Komposisi selular seperti sel, cairan ekstrasel dan bagian padat ekstrasel. Dan komposisi jaringan dan organ berupa jaringan adiposa, otot skelet, tulang, kulit dan organ dalam. 1,2 Kelebihan gizi digolongkan menjadi overweight dan obesitas dengan indeks massa tubuh (IMT) $\geq \mathrm{kg} / \mathrm{m}^{2}$. $^{3}$

Menurut World Health Organization (WHO) pada tahun 2015 sekitar 2,3 miliar penduduk usia dewasa di seluruh dunia mengalami overweight, dan lebih dari 700 juga mengalami obesitas. ${ }^{2}$ Berdasarkan data RISKESDAS 2010, terjadi peningkatan prevalensi obesitas pada tiap kelompok usia. Masalah overweight dan obesitas di Indonesia saat ini terjadi pada tiap kelompok usia da pada semua strata sosial ekonomi. Hasil RISKESDAS tahun 2010 ini menunjukan prevalensi overweight dan obesitas pada usia sekolah dan usia remaja mencapai $9,2 \%{ }^{3}$

Overweight dan obesitas pada anak berisiko akan berlanjut pada masa remaja dan dewasa dan merupakan faktor risiko terjadinya berbagai penyakit metabolik seperti diabetes melitus dan hipertensi yang berhubungan dengan meningkatnya morbiditas pada usia muda. ${ }^{2}$ Pola makan seperti mengonsumsi makanan melebihi dari kebutuhan kalori tubuh, tinggi lemak, tinggi karbohidrat dan rendah serat, merupakan pencetus utama terjadinya overweight dan obesitas. Sedangkan keadaan ini juga sangat dipengaruhi oleh berkurangannya aktivitas fisik dan perilaku makan yang salah seperti lebih banyak mengonsumsi makanan cepat saji dan minuman ringan tiap harinya. ${ }^{4}$

Dilaporkan bahwa peningkatan berat badan berhubungan dengan penyakit kardiovaskular dan meningkatnya angka morbiditas dan mortalitas. ${ }^{5}$ The National Cholesterol Education Program (NCEP) melaporkan hasil analisis profil lipid dapat menilai risiko kelainan kardiovaskular dan penyakit lainnya (NCEP, 2002). Sedangkan aktivitas fisik secara teratur tiap harinya berhubungan dengan penurunan besaran profil lipid pada pasien overweight dan obesitas. ${ }^{6}$

Keadaan ini perlu ditanggulangi untuk mencegah tingginya prevalensi penyakit metabolik pada penduduk Indonesia khususnya pada usia produktif. Oleh karena itu penelitian in bertujuan untuk menilai pengaruh terapi gizi klinik intensif terhadap penurunan berat badan, komposisi tubuh, dan profil lipid pada mahasiswa fakultas kedokteran dan ilmu kesehatan usia remaja yang mengalami overweight dan obesitas. 


\section{METODE}

Penelitian ini merupakan penelitian case control untuk menilai perbedaan pengaruh intervensi antara terapi gizi intensif dengan penyuluhan gizi secara umum pada penurunan berat badan, komposisi tubuh, dan profil lipid. Sampel merupakan mahasiswa Fakultas Kedokteran dan Ilmu Kesehatan Universitas Jambi usia 18-21 tahun, sehat dan memiliki IMT $\geq 23$, yang terbagi dalam 15 orang kelompok case dan 15 orang kelompok control. Sampel yang sedang menjalani diet dan pengobatan jangka panjang dikeluarkan dari penelitian.

Penelitian ini dilakukan selama bulan Agustus - September 2018, dimana sampel penelitian akan dilakukan pemeriksaan antopometri, komposisi tubuh dan profil lipid sebelum dan sesudah intervensi. Sebelum menjalani pemeriksaan, dilakukan food recall pada sampel untuk menilai asupan makanan selama 1×24 jam. Sampel pada tiap kelompok menjalani pemeriksaan antopometri, komposisi tubuh, dan profil lipid sebelum diberikan intervensi gizi. Pemeriksaan profil lipid pada penelitian ini bekerjasama dengan Laboratorium Prodia Jambi. Sedangkan pemeriksaan komposisi tubuh menggunakan TANITA body scale.

Kelompok case akan diberikan intervensi berupa terapi gizi intensif selama empat kali dalam sebulan sedangkan kelompok control hanya mendapatkan satu kali penyuluhan gizi secara umum. Setelah intervensi tersebut, dilakukan kembali pemeriksaan antopometri berupa berat badan, komposisi tubuh, dan profil lipid. Kemudian hasil tiap kelompok dibandingkan untuk menilai sejauh apa pengaruh terapi gizi intensif dalam menurunkan berat badan, komposisi tubuh, dan profil lipid dibandingkan hanya diberikan penyuluhan gizi saja. Analisis data menggunakan uji T tidak berpasangan dalam SPSS.

\section{HASIL DAN PEMBAHASAN}

Dari hasil penelitian didapatkan karakteristik subjek penelitian dalam kelompok case dan kelompok control sebagai berikut:

Tabel 1. Karakteristik Umum Subjek pada Kelompok Case dan Control

\begin{tabular}{|c|c|c|c|c|}
\hline \multirow{2}{*}{$\begin{array}{c}\text { Karakteristi } \\
\text { k }\end{array}$} & \multicolumn{2}{|c|}{ Case } & \multicolumn{2}{|c|}{ Control } \\
\hline & Nilai* & $n$ & Nilai $^{*}$ & $\mathrm{n}$ \\
\hline \multicolumn{5}{|l|}{ Jenis } \\
\hline \multicolumn{5}{|l|}{ kelamin } \\
\hline \multirow[t]{2}{*}{ Laki-laki } & & $4(26,7)$ & & $8(53,3)$ \\
\hline & & 11 & & $7(46,7)$ \\
\hline Perempuan & & $(73,3)$ & & \\
\hline Usia & $\begin{array}{c}19,53 \pm 1 \\
598\end{array}$ & & $\begin{array}{c}20,20 \pm 1 \\
74\end{array}$ & \\
\hline IMT & $\begin{array}{c}29,27 \pm 4 \\
24\end{array}$ & & $\begin{array}{c}29,27 \pm 4 \\
24\end{array}$ & \\
\hline \multicolumn{5}{|l|}{ Profil lipid } \\
\hline \multicolumn{5}{|l|}{ Kolesterol } \\
\hline Normal & & $10(66,7$ & & $9(60)$ \\
\hline Tinggi & & $5(33,3)$ & & $6(40)$ \\
\hline \multicolumn{5}{|l|}{ LDL } \\
\hline Normal & & $12(80)$ & & $12(80)$ \\
\hline Tinggi & & $3(20)$ & & $3(20)$ \\
\hline \multicolumn{5}{|l|}{ HDL } \\
\hline Normal & & $11(73,3$ & & $11(73,3)$ \\
\hline Tinggi & & $4(26,7)$ & & $4(26,7)$ \\
\hline
\end{tabular}




$\begin{array}{lr}\text { Normal } & 14(93,) \\ \text { Tinggi } & 1(6,7)\end{array}$

\section{Komposisi}

Tubuh

Massa

Lemak

Massa Otot

$36,2 \pm 8,5$

1

$45,4 \pm 8,6$

4

Massa

Tulang

Cairan

Tubuh

Massa

Bebas

Lemak

Berat Badan 75,88 \pm 14

(Kg)

, 77

Gula Darah

$85,67 \pm 13$

Puasa

, 89

(mg\%)

\begin{tabular}{lccc} 
(mg\%) & & No \\
\cline { 4 - 4 } Asupan & & & $\mathbf{1}$ \\
Makanan & & & $\mathbf{2}$ \\
Energi (kcal) & $1515,2 \pm 5$ & 02,77 & \\
& 10,65 & $58,2 \pm 23$, & \\
Protein (gr) & $54,6 \pm 22$, & 59 & \\
& 66 & $1758,7 \pm 5$ & \\
Lemak (gr) & $61,3 \pm 32$, & 1 & $\mathbf{3}$ \\
& 59 & $228,1 \pm 80$ & \\
Karbohidrat & $187,8 \pm 67$ & $7,8 \pm 4,17$ & \\
(gr) &, 88 & &
\end{tabular}

\section{Dapat dilihat pada tabel 1 didapatkan bahwa perempuan} mendominasi subjek pada kelompok case (73,3\%) dengan rerata usia adalah 19,53 tahun dan rerata IMT adalah 29,27, sedangkan pada subjek kelompok control didominasi oleh laki-laki (53,3\%) dengan rerata usia subjek adalah 20,20 tahun dan
14(93,3 rerata IMT 28,20. didapatkan hasil $1(6,7)$ persentase rerata dari tiap item profil lipid pada kedua kelompok sebenarnya tidak jauh berbeda, hanya tampak sedikit berbeda pada hasil pemeriksaan kolesterol total dimana kadar normal pada kelompok case lebih tinggi daripada kelompok control $(66,7 \%$ : 60\%). Sedangkan rerata komposisi tubuh pada kedua kelompok hanya menggambarkan kandungan gizi pada tubuh tiap subjek penelitian saja, begitupun untuk asupan makanan harian yang didapatkan dari data food recall 1x24 jam sebelum sampel diberikan intervensi gizi. Dengan hasil antara kedua kelompok penelitian yang tidak terlalu berbeda.

Tabel 2. Perbedaan BB, Komposisi Tubuh, dan Profil Lipid pada Kelompok Case Sebelum dan Sesudah Intervensi Gizi

\begin{tabular}{|c|c|c|c|}
\hline No & Karakteristik & $\begin{array}{c}\text { Sebelum } \\
\text { (rerata) }\end{array}$ & $\begin{array}{c}\text { Sesudah } \\
\text { (rerata) }\end{array}$ \\
\hline 1 & Berat Badan (Kg) & 75,88 & 74,54 \\
\hline \multirow[t]{7}{*}{2} & Komposisi Tubuh & & \\
\hline & Massa Lemak & 36,2 & 34,53 \\
\hline & Massa Otot & 45,4 & 45,78 \\
\hline & Massa Tulang & 2,66 & 2,69 \\
\hline & Cairan Tubuh & 42,5 & 43,77 \\
\hline & Massa Bebas Lemak & 9,60 & 8,8 \\
\hline & Gula Darah Puasa (mg\%) & 85,67 & 94,8 \\
\hline \multirow[t]{11}{*}{3} & Profil Lipid & & \\
\hline & Kolesterol Total & & \\
\hline & Normal $(<200)$ & 66,7 & 80 \\
\hline & Tinggi (>200) & 33,3 & 20 \\
\hline & LDL & & \\
\hline & Normal $(<130)$ & 80 & 86,7 \\
\hline & Tinggi (>130) & 20 & 13,3 \\
\hline & HDL & & \\
\hline & Normal $(>40)$ & 73,3 & 60 \\
\hline & Rendah $(<40)$ & 26,7 & 40 \\
\hline & Trigliserida & & \\
\hline
\end{tabular}




\begin{tabular}{lcc} 
Normal $(<150)$ & 93,3 & 93,3 \\
Tinggi $(>150)$ & 6,7 & 6,7 \\
\hline
\end{tabular}

Pada tabel 2, dapat dilihat perbedaan hasil pemeriksaan berat badan, komposisi tubuh, dan profil lipid pada kelompok case sebelum dan sesudah menjalani terapi gizi intensif selama satu bulan. Berat badan setelah intervensi gizi tampak menurun sekitar $1 \mathrm{~kg}$. Terjadi penurunan pada massa lemak yang menjadi item dari komposisi tubuh pada kelompok case dan peningkatan massa otot setelah diberikan intervensi gizi klinis. Untuk rerata nilai profil lipid pada kelompok case juga terjadi peningkatan kadar nilai normal pada item pemeriksaan kolesterol total dan LDL meskipun nilai HDL dan Trigliserida tidak mengalami perubahan.

$$
\text { Tabel } 3 \text { menggambarkan }
$$

perbedaan rerata berat badan, komposisi tubuh, dan profil lipid pada kelompok control sebelum dan sesudah diberikan satu kali penyuluhan gizi.

Tabel 3. Perbedaan BB, Komposisi Tubuh, dan Profil Lipid pada Kelompok Control Sebelum dan Sesudah Penyuluhan Gizi

\begin{tabular}{clcc}
\hline No & \multicolumn{1}{c}{ Karakteristik } & $\begin{array}{c}\text { Sebelum } \\
\text { (rerata) }\end{array}$ & $\begin{array}{c}\text { Sesudah } \\
\text { (rerata) }\end{array}$ \\
\hline $\mathbf{1}$ & Berat Badan (Kg) & 74,54 & 74,14 \\
$\mathbf{2}$ & Komposisi Tubuh & & \\
& Massa Lemak & 29,98 & 30,92 \\
& Massa Otot & 49,26 & 48,26 \\
& Massa Tulang & 2,74 & 2,73 \\
& Cairan Tubuh & 45,3 & 45,78 \\
& Massa Bebas Lemak & 10,20 & 9,20 \\
& Gula Darah Puasa (mg\%) & 86,87 & 94,3 \\
& Profil Lipid & &
\end{tabular}

\begin{tabular}{lcc} 
Kolesterol Total & & \\
Normal $(<200)$ & 60 & 73,3 \\
Tinggi $(>200)$ & 40 & 26,7 \\
LDL & & \\
Normal $(<130)$ & 80 & 73,3 \\
Tinggi $(>130)$ & 20 & 26,7 \\
HDL & & \\
Normal $(>40)$ & 73,3 & 80 \\
Rendah $(<40)$ & 26,7 & 20 \\
Trigliserida & & \\
Normal $(<150)$ & 93,3 & 93,3 \\
Tinggi $(>150)$ & 6,7 & 6,7 \\
\hline
\end{tabular}

Gambaran rerata perbedaan nilai antar variabel yang tidak berbeda secara signifikan. Berat badan setelah diberikan penyuluhan gizi tidak terjadi penurunan secara signifikan. Begitu pun untuk perbedaan rerata nilai komposisi tubuh yang juga tidak banyak mengalami penurunan setelah diberikan penyuluhan gizi. Sedangkan rerata nilai profil lipid tampak mengalami peningkatan pada kadar nilai normal kolesterol total dan HDL, namun menurun pada kadar nilai LDL dan tetap pada kadar Trigliserida.

Dilakukan analisis pula untuk menilai adakah perbedaan bermakna antara intervensi terapi gizi intensif dengan penyuluhan gizi dalam menurunkan berat badan, komposisi tubuh, dan profil lipid. Dan didapatkan hasil dari uji T tidak berpasangan pada variabel penelitian ini adalah nilai sign (2-tailed) > 0,05, sehingga dapat disimpulkan bahwa tidak ada perbedaan bermakna antara terapi gizi klinis dan penyuluhan gizi terhadap penurunan nilai BB, komposisi tubuh, dan profil lipid pada subjek penelitian ini. 
Berdasarkan dari hasil penelitian ini didapatkan simpulan bahwa prevalensi overweight dan obesitas pada subjek dikedua kelompok ini tersebar hampir merata. Dengan jenis kelamin yang saling mendominasi antar kelompok dan rerata usia 19-20 tahun. Begitupun untuk nilai rerata profil lipid dan komposisi tubuh pada subjek di tiap kelompok. Prevalensi obesitas di Indonesia menurut Riset Kesehatan Dasar (Riskesdas) 2013 di DKI Jakarta pada remaja umur 16-18 tahun sebanyak 7,3\%, pada umur >18 tahun sebesar 15,4\%, prevalensi obesitas pada laki-laki pada tahun 2013 sebanyak 19,7\% lebih tinggi dari tahun 2007 (13,9\%), prevalensi obesitas perempuan dewasa (>18 tahun) 32,9\% naik 17,5\% dari tahun 2010 (15,5\%).

Penelitian You dkk yang dilakukan di Korea pada 22 perempuan remaja yang mengalami obesitas dan dari hasil penelitian yang dilakukan oleh Pem dkk dalam menilai pengaruh intervensi gizi dalam mengatasi obesitas, didapatkan data kedua kelompok penelitian yang dilakukan pemeriksaan BB, IMT, dan komposisi tubuh, namun dapat penelitian tersebut tidak dijabarkan gambaran perbedaan BB, IMT dan komposisi tubuh pada kedua kelompok penelitian. Pada kedua penelitian tersebut, hanya membandingkan perbedaan hasil BB, IMT, Komposisi tubuh, dan profil lipid sebelum dan sesudah intervensi gizi, sama seperti penelitian ini.7,9

Gambaran rerata hasil pemeriksaan berat badan, komposisi tubuh dan profil lipid setelah intervensi gizi selama satu bulan pada kelompok case didapatkan penurunan berat badan, massa lemak, dan peningkatan massa otot setelah diberikan intervensi gizi klinis. Untuk rerata nilai profil lipid pada kelompok case juga terjadi peningkatan kadar nilai normal kolesterol total dan LDL meskipun nilai HDL dan Trigliserida tidak mengalami perubahan. Perbedaan hasil pemeriksaan ini dapat menggambarkan peranan terapi gizi klinis yang diterapkan untuk menurunkan berat badan, komposisi tubuh dan kadar profil lipid pada kasus overweight dan obesitas.

Berdasarkan penelitian yang dilakukan You dkk yang dilakukan di Korea, didapatkan hasil penurunan kadar profil lipid pada populasi Korea yang menerapkan diet sehat dan suplemen gizi tertentu selama 8 minggu sebagai bentuk intervensi gizi dalam penelitian mereka. $^{7}$

Sedangkan hasil dari sebelum dan sesudah pemberian penyuluhan gizi pada kelompok control tidak berbeda secara signifikan. Hanya nilai berat badan yang mengalami penurunan dan peningkatan kadar nilai normal kolesterol total dan HDL saja. Sedangkan untuk komposisi tubuh tidak banyak tampak perbedaan nilai setelah pemberian penyuluhan gizi.

Berdasarkan hasil penelitian yang dilakukan oleh You dkk pada tahun 2009 di Korea mengenai intervensi gizi berupa penyuluhan gizi dan pemberian suplementasi pada 22 wanita remaja selama 8 minggu juga didapatkan hasil penurunan massa lemak tubuh, massa lemak bebas dan tentunya penurunan berat badan sehingga ikut berpengaruh pada penurunan indeks massa tubuh. Hasil Penelitian yang dilakukan oleh Matvienko dkk di United State pada tahun 2001 didapatkan 
terjadinya penurunan berat badan pada 40 sampel wanita usia sekolah yang diberi intervensi berupa penyuluhan tentang pengetahuan gizi selama 16 bulan. ${ }^{7,8}$

Dari hasil uji $\mathrm{T}$ tidak berpasangan yang dilakukan untuk menilai perbedaan pengaruh terapi gizi klinis dengan penyuluhan gizi secara umum pada subjek penelitian menunjukkan tidak ada perbedaan yang signifikan dalam menurunkan BB, komposisi tubuh, dan profil lipid. Umumnya terapi gizi klinis dapat menurunkan BB, komposisi tubuh, dan profil lipid dibandingkan hanya diberikan penyuluhan gizi saja.

Seperti pada penelitian Pem dkk, didapatkan pengaruh yang signifikan dalam menurunkan konsumsi gula dan lemak $(P<0,05)$, sedangkan tidak ada pengaruh yang signifikan dalam menurunkan berat badan dan IMT pada kelompok yang diberikan intervensi gizi $(P>0,05)$ dibandingkan kelompok kontrol. Keterbatasan dari penelitian ini adalah waktu intervensi yang cukup singkat yaitu 12 minggu sehingga tidak dapat menggambarkan perbedaan hasil pengukuran BB dan IMT dan food recall yang dilakukan selama 3 hari tidak cukup menggambarkan kebiasaan diet subjek penelitian tersebut . ${ }^{7}$

Beberapa kelemahan yang didapatkan dari penelitian ini dalam menilai perbedaan pengaruh terapi gizi klinis dengan penyuluhan gizi adalah waktu intervensi yang sangat singkat yaitu hanya berjalan 4 minggu, disertai jumlah subjek penelitian yang juga terbatas ditiap kelompok yaitu 15 subjek tiap kelompok dan pemantauan kandungan makanan menggunakan food recall hanya 1x24 jam. Singkatnya durasi intervensi dan terbatasnya jumlah subjek penelitian ini menyebabkan belum tercapainya penurunan berat badan, komposisi tubuh serta profil lipid.

\section{KESIMPULAN DAN SARAN}

Pada penelitian ini tidak didapatkan perbedaan bermakna antara terapi gizi intensif dibandingkan dengan penyuluhan gizi saja dalam menurunkan berat badan, komposisi tubuh, dan profil lipid. Akan tetapi terdapat perbedaan pada berat badan, profil lipid, dan komposisi tubuh sebelum dan sesudah intervensi pada kelompok case dan control.

Saran untuk penelitian berikutnya agar cakupan subjek penelitian diperluas sehingga bisa didapatkan data profil remaja overweight dan obesitas di provinsi Jambi yang lebih banyak dan beragam serta menambah durasi intervensi gizi dengan pemantauan food recall yang lebih mendalam. 


\section{DAFTAR PUSTAKA}

1. World Health Organization. 2016. Obesity and overweight, fact sheet, Updated June 2016. http://www.who.int/mediacentre/factsheets/fs311/en/ (accessed 19 February 2018).

2. National Institute for Health and Care Excellence, Obesity: identification, assessment and management of overweight and obesity in children, young people and adults. 2014, NICE: UK.

3. Kementerian Kesehatan. 2013. Riset Kesehatan Dasar 2013. http://www.depkes.go.id/resources/download/general/Hasil\%20Riskesdas\%202013.pdf.

4. Badr SAEF, Denna S, Effects of Diet Control and Physical Activity for 10 Weeks on Body Mass Index and Lipid Profile, 2015, EDAM: Libya.

5. Poirier P, Despres JP, Exercise in weight management of obesity. 2001, Cardiology Clinics, 19(3), hal. 459470

6. National Cholesterol Education Program, Expert panel on detection, evaluation and treatment of high blood cholesterol in adults (Third report of the National Cholesterol Education Program (NCEP) adult treatment panel III final report). 2002, Circulation, 106, hal. 3143-3421.

7. You JS, Sung MJ, Chang KJ. Evaluation of 8-week body weight control program including sea tangle (Laminaria japonica) supplementation in Korean female college students. Nutr Res Prac. 2009;3(4):307314.

8. Matvienko O, Lewis DS, Schafer E. A college nutrition science course as an intervention to prevent weight gain in female college freshman. J Nutr Educ. 2001;33(2):95-101.

9. Pem D, Bhagwant S, Jeewon R. A pre and post survey to determine effectiveness of a dietitian-based nutrition education strategy on gruit and vegetable intake and energy intake among adults. Nuts Mdpi. 2016: 8(127). 